\title{
Creating the Past, and Still Counting the Losses: Evaluating Narrative of the Nigerian Civil War in Buchi Emecheta's DESTINATION BIAFRA
}

\author{
Niyi Akingbe*
}

\begin{abstract}
Buchi Emecheta's Destination Biafra chronicles happenings of the Nigerian civil war. The criticism in the novel is directed at the greed, corruption and sadism of many of the protagonists on all sides which suitably demonstrates the illogicality of seeking to explain the war. This paper articulates how Emecheta's Destination Biafra brings new perspectives to bear upon a significant aspect of Nigerian history that has been dominated by one segment of society. In this particular case, interpretations of the Nigerian civil war, hitherto controlled by men, are moderated by an essentially female account. The paper historicizes the trauma and scars borne by women and children during the war, focusing mainly on how the war is stripped of the glamour which masculinist accounts often endow it with, and how this is seen in all its senselessness and brutality. Just as the belligerents fight over resources and territory, so are accounts of what took place during the conflict being fought over between those who prosecuted it and those who were its victims.
\end{abstract}

Keywords: creating the past, counting the losses, Nigerian civil war, evaluating, narrative

\footnotetext{
* Corresponding author: Niyi Akingbe, Department of English, Joseph Ayo Babalola University, IkejiArakeji, Osun state, Nigeria, e-mail: nakingbe@yahoo.com
} 


\section{Introduction}

In Destination Biafra, Buchi Emecheta's ambitious novel of the Nigerian Civil War, engrained stereotypes of women are interrogated. By choosing to focus on civil war, Emecheta seeks to deconstruct the masculinist assumptions that are inherent in the unquestioned notion of a "fratricidal" conflict in which women and children constitute no more than collateral damage. Her outrage then, is not just about the horror and waste of war, but is more fundamentally directed against the testosterone-driven political struggles that make it inevitable. This is in fulfillment of the observation of the celebrated South African novelist and critic, Nadine Gordimer, who observes that, 'writers choose their plots, characters and literary styles; their themes choose them....in this sense, the writer is the voice of the people beyond any glib political connotations of the phrase.'(1) Consequently, an important aspect of Nigeria's turbulent history therefore becomes a resource for constructing a discourse in Destination Biafra.

This paper seeks to examine how Emecheta's position as a female writer provides her a privileged point from which to view how the Nigerian Civil War between 1967-1970, affected women and children in Destination Biafra. Through abundant use of metaphors, allegory and allusive names, the writer demands a second-level reading of the novel as both historical and political statements on an important segment of Nigeria's political history. My objective in this essay is not only to highlight the use of history in the narrative of Emecheta's Destination Biafra, but also to discuss the significance of such use of history in order to establish artistic concern of Emecheta as it impinges on the dehumanization of her female characters in the novel.

Africa's most populous nation, Nigeria, like many other independent countries in Africa with the exception of Ethiopia, are products of imperialism and colonialism, its culturally variegated ethnic groupings locked into a nation- state they had had no part in designing. Before the European conquest, Nigeria was home to an estimated three hundred ethnic groups of sometimes widely differing languages and systems of internal rule. Although its constituents had traded and often 
lived among each other for centuries, the land of Nigeria had never existed as one political unit. The peoples gathered within its borders had different cultures and stood at very unequal levels of development, a state of affairs that once prompted the Yoruba nationalist leader Obafemi Awolowo to describe Nigeria as a 'mere geographical expression' (Maier,7-8).

Although Nigeria became an independent nation in 1960, in the mid to late 1960s, disillusionment gradually crept in to reflect the sense of dismay with corruption and ethnic chauvinism perpetrated by the first generation crop of Nigerian politicians, this is represented in Chinua Achebe's A Man Of the People (1966), a foremost post-independence critical novel, which condemns corruption in Nigerian socio-political landscape. In the novel, Achebe paints an uncompromisingly scathing portrait of the first generation of Nigeria's politicians in the figure of the corrupt Chief Nanga, whose patronage of the young protagonist, Odili Samalu, exposes him to the temptations of post-independence Nigeria political life. This pervading tone of disillusionment with corruption and dismay performance of the politicians developed into discord between various ethnic groupings, internal struggles, and to a number of violent civil conflicts which eventually snowballed into the Nigerian Civil War of 1967-70.

The attempt to build a novel about Nigeria's political imbalance which led to the historic Civil War on the basis of memory has been shown to be irresistible challenge and a compelling necessity for many Nigerian Civil War novelists. There seems to be a palpable obsession to set down, with or without the help of fiction, the collection of memories that form the writer's idea of the Civil War, perhaps in an attempt to reconcile both past and present. In one of the recent studies of books on the Nigerian civil War, Craig McLuckie has observed that between 1970 and 1990 more than "twenty-nine works have been written about the Civil War. Moreover, ten autobiographies have also been identified." (9) This includes early texts, such as S.O. Mezu's Behind the Rising Sun(1971), Chinua Achebe's Girls at War(1972), Kole Omotoso's The Combat(1972) and I.N.C.Aniebo's The Anonymity of Sacrifice(1974),Isidore Okpewho's The Last Duty(1976), Cyprian 
Ekwensi's Survive the peace(1976) and Divided We Stand(1980) Buchi Emecheta's Destination Biafra(1982), Eddie Iroh's The Siren in the Night(1982), Kalu Okpi's Biafra Testament(1982), Ossie Enekwe's Come Thunder(1984), Flora Nwapa's Wives at War(1984), Elechi Amadi's Sunset in Biafra(1978) and Estrangement(1986),Festus Iyayi's Heroes(1986), and wole Soyinka's The Man Died(1979),Season of Anomy(1980)and Madmen and Specialists(1984). In the recent time, new titles have been added to the list: Anthonia Kalu's Broken Lives and other stories(2003), Chimamanda Ngozi Adichie's Half of the Yellow Sun(2006 ) and Uzodinma Iweala's Beasts of No Nation(2005).

Emecheta's novelistic concerns have stimulated feminism in Nigerian literature. She has been able to articulate women's position in Nigeria's social milieu by reconstructing the stereotypical perception of women as objects of procreation and being socially inferior to their male counterparts. Some of her works include: In the Ditch; Second Class Citizen, The Slave Girl, The Bride Price, The Family, Head Above Water, The Rape of Shavi and The Joys of Motherhood. Emecheta has also written two children's texts: The Wrestling Match and The Moonlight Bride. It is interesting to note that the central theme in most of Emecheta's novels foreground economic exploitation and denial of opportunity of the female for the expressed benefit of the male, The Bride Price(1976) and The Slave Girl(1977) vividly explore this theme in details. Emecheta has also interrogated, and reassesed identity crisis foisted upon women, especially the stereotypical portrayal of women as weak and vulnerable in male-authored literary works as evident in, Chinua Achebe's Things Fall Apart(1957), Arrow of God(1964) and Elechi Amadi's The Concubine(1966).In these novels, Emecheta has vehemently criticized the ostensible crafting of the female characters as weaklings and sex objects. Alternatively, strong female characters have been created in In the Ditch(1972),Second-Class Citizen(1974), The Bride Price(1976) and The Joys of Motherhood(1979).In The Joys of Motherhood, for instance, Emecheta portrayed a strong-willed character, Ona, who prefers to live with Agbadi as mistress rather than wife. Emecheta's texts re-write earlier male texts by creating female characters who defy cultural barriers, and heroically struggle for survival and 
subsequently make progress in the face of enormous odds placed in their way by a stiffling male-dominated social structure. "Like other earlier African women writers, her texts re-write earlier male texts. They also establish an intertexuality with these earlier women's texts, creating and adding to the distinctive tradition of African women's writing by direct allusion, and by extending and developing the radical new modes of representation these earlier texts embodied.'(Griffiths,300). However, Emecheta's creation of weak male characters in her works: social misfits in In the Ditch, vicious Pa Palagada in The Slave Girl, Nnaife in Joys Of Motherhood and Francis in Second Class Citizen portrayed as effeminate, insensitive and irresponsible heads of families, has attracted sharp criticism from critics. In the view of Catherine Acholonu, Emecheta "overstepped her bounds in her portrayal of male characters in exaggerated state of idiocy, irresponsibility and insensitivity (which) reduces the plausibility and reliability of her point of view.' (Acholonu, 13).

\section{An appraisal of Nigeria's historical-political trajectory}

Buchi Emecheta's Destination Biafra, Eddie Iroh's Toads of War, Flora Nwapa's Women at War and Chimamanda Ngozi Adichie's Half of a Yellow Sun are few Nigerian war novels where women are present and at times play active roles. But Emecheta's Destination Biafra is unique, in the sense that it chronicles untold tales of the Nigerian Civil War. These tales are untold because, while other Nigerian war novels where women are involved are replete with accounts of mass deprivation and suffering during the three-year old conflict, but they do not describe them in the necessarily individual terms that is vital if the enormity of the conflict's trauma is to be properly understood. Since a proper accounting of the war's moral cost is also dependent upon a clear identification and indictment of those whose ambition, arrogance and greed made such suffering both inevitable and unnecessary. At a superficial evaluation, the Nigerian civil war is symptomatic of a supremacy tussle between General Gowon and Colonel Ojukwu. But at a wider perception, the civil war reflects the divisions between the various ethnic groups carelessly yoked together in the colonial construction of Nigeria. Tension generated by the 
political divisions among Nigeria's ethnic groups especially between the Hausa in the north, and the Igbo in the south-east reached its apogee when Major Chukwuma Nzeogwu Kaduna staged 15 January 1966 coup. The coup was perceived by many as an Igbo attempt to take over the country. Six months later a counter coup was staged on 29 July 1966 by Hausa officers, who installed General Yakubu Gowon as head of state. This led to riots in the north which resulted in to the massive killing of Igbos. In 1967, the Igbos, under the leadership of Colonel Ojukwu, attempted to secede as the Republic of Biafra, but was resisted by the Hausa-led federal government. This led to a bloody civil war which lasted until 1970 with attendant hundreds of thousands of casualties. Emecheta's Destination Biafra is a vibrant product of the Nigerian War literature, which constitutes a major corpus of Nigerian literature, and its significance has been evaluated in a question raised by Chinyere Nwahunanya: "What is the place of Nigerian war literature in the African political and literary experience?', the answer to this germane question seems to be embedded in an editorial remark of A Harvest from Tragedy: Critical perspectives on Nigerian Civil War Literature :

In its re-creation and interpretation of history, Nigerian war Literature has enriched the existing body of historical writing From Africa (,) especially historical fiction. In this way the writers have made literature Continue to function as the mirror of society. In the process of mirroring society and criticizing its pitfalls, the war literature also serves as a compass for social redirection. (14)

Destination Biafra revolves around Debbie Ogedemgbe, who started as a precocious young woman, a daughter of Samuel Ogedemgbe, Nigeria's minister of finance. When the war broke out, she was sent on a government-approved mission to see Chijioke Abosi, as to persuade him to discontinue with his plans for secession. The various experiences she undergoes in her journey to the Biafra expose her to the harsh realities of war in such a way that she is able to clearly see the posturing, insincerity and plain viciousness of the men who purport to be in charge. She is faced with the stark reality of the fact that women and children, who have no blame for the outbreak of war, are ironically its greatest casualties. Women are raped, bodies are dismembered and vulnerable human beings 
are made to face every form of degradation imaginable. As Emecheta is at pains to point out, Debbie experiences these things at first-hand:

\begin{abstract}
Debbie heard the slap on her mother's face and it burned into all the nerve fibres of her body. She kicked out at one of the men holding her and heard him cry in pain. Her punishment was that the men fell on her. She could make out the figure of the leader referred to as Bale on top of her. Then she knew it was somebody else, then another person.... She felt herself bleeding, though her head was still clear.... The Ibo woman and Stella Ogedemgbe dug a shallow grave for the dead young mother and her two babies; the soldiers had cut her open and killed her unborn child, saying, "Who knows, he might live to be another Abosi." (134-135)
\end{abstract}

The serial violations of Debbie and her mother, and the mutilation of the unnamed Ibo woman by the militia is a measure of the extent to which Emecheta's writing strives to discuss graphically the condition and status of women as perceived by their male counterparts in Africa during political crises and civil wars: as objects to be pillaged, degraded and exploited, much like any other item of booty. The multiple rape of Debbie and her mother, violently inscribed a condemnation of predatory masculinity within the novel's sociological evaluation .Ostensibly, masculine power is devalued and repudiated. The graphic analysis of the scenario of the rape in the novel, is what Ann Marie Adams has described as "portions of the war that other narratives only gloss or allude to."'(295) the agonies felt from the brutalisation of the women in the novel could arguably only be vividly captured by a woman writer whose membership of the same gender imbues her with the necessary insight needed to present the inner feelings of women in the light of their experiences from their point of view. This betrays popular persuasion of most female writers in their strive to change the status of women in the society, as succinctly opined by Eldred Durosimi Jones:

A significant development since independence has been

The increasing importance of women writers and the consequent

Focus on women's situation in society, their pre-occupations with family and work,

And their attempts to free themselves from the trammels of tradition. (1)

The need to restore dignity of women is what has influenced Emecheta's preoccupation with the recuperation of past history of the humiliation of 
women in the novel, which in itself is a form of protest. By returning to the past, with all its pain and trauma, she is stating that the story of the Nigerian Civil war is incomplete if it does not accurately and honestly depict the victimisation, maltreatment and brutalisation of its most vulnerable victims. She demands vehemently that, in the narration of the condition and situation of women as an endangered species during the Nigerian Civil War, there must be no ruptures, no silences, and no fragmentation. As a significant event occurring in the past, it must be fully narrated within the present moment in such a way that there is no ambiguity, and by extension, no repression of the truth of what happened. The depiction of the grotesque brutality of women in the novel, can be seen as an attempt by Emecheta to address the gendered bias of discourse on the war, as exemplified essentially in the novels written by male writers.

The dialectics of historical narration are poignantly captured by Iniobong I. Uko:

Evidently, the coming of age of African literature is identifiable by the true and pragmatic feminisation of the literary vision as a way of correcting absurd female images in African literature and culture. Here, the female explores the inner fibres of the androgynous ideal, thereby establishing and justifying the position of women. (82)

This underscores the fact that only female writers could conveniently discuss and meaningfully analyse the physical stress and psychological trauma her fellow woman is subjected to.

Destination Biafra recreates through fictionalisation of an actual occurrence the lopsidedness of power distribution at the attainment of independence in Nigeria in 1960, and the way in which it aggravated the tensions and distrust which eventually led to the Nigerian Civil War. Interestingly enough, although the primary focus of Emecheta is on the consequences of the Nigerian Civil War, especially as it affected women and children, she also takes cognisance of the amoral manipulation of Nigerian ethnic groups against one another by the British colonial authorities. Nigerian history becomes the basis for reconstructing a discourse of nationalism away from the platitudes and insincerities 
recounted in conventional histories. This resonates Isabel Allende's remark that "in a novel we can give an illusory order to chaos. We can find the key to the labyrinth of history. We can make excursions into the past, to try to understand the present and dream the future. In a novel we can use everything: testimony ,chronicle, essay, fantasy, legend, poetry and other devices that might help us to decode the mysteries of our world and discover our true identity' (45) In this manner, through her literary revision of activities in the short-lived Biafra and Nigeria itself, Emecheta ultimately presents a portrait of the essentially ambiguous nature of Nigeria's creation, and the vital necessity of clearly identifying who did what to whom during the most trying period of its postindependence history. Unlike Eddie Iroh's The Siren in the Night (1982), which demands that the narrative of the war should strive to make "an unbiased total assessment of the whole great tragedy.'(Hawley,18) Iroh ostensibly asks that for any narrative of the Biafran war to be taken serious, it must be mediated by the objective rendering of facts; and the war experience be presented as tragedy. Though this Iroh's prescription is idealistic, however in undertaken a seemingly objective narration of the Nigerian civil war, Emecheta links Nigeria's history with personal history especially in the relationship of her main characters, Saka Mohmoh (Gowon) and Chijioke Abosi (Ojukwu).This is grounded in allegorical evaluation of Abosi and Mohmoh's wives inability to have children in the novel. While Abosi's wife suffered repeated miscarriages, Mohmoh's wife gives birth to a still born (193). This significantly implies that the death of a child signifies that a new nation can not be born: Biafra is an abortive effort and the 'new' Nigeria, without its seceded peoples and under an abusive military regime, is monstrous and incomplete.

\section{Biafra as a creative recollection}

With its utilisation of fictional names for Nigeria's three main ethnic groups, Destination Biafra is anchored in creative recollection. The novel is based on Debbie Ogedemgbe's painful experiences which, in reality, acutally invite repression rather than remembrance. Recollection, viewed from a postmodern perspective, always implicates loss or forgetting. Even though Emecheta interprets Nigeria using different codes and from different positions, they are all overshadowed by a prevalent sense of loss. The author has acknowledged in the 
foreword of the novel that she was not in Nigeria when the civil war was fought, but participated in the students' demonstration against the war at Trafalgar Square in London at the time. However, her loss in the novel is demonstrated in her dedication of the novel to the memory of many relatives and friends who died in this war, especially "my eight-year old niece, Buchi Emecheta, who died of starvation, and her four-year old sister Ndidi Emecheta who died two days afterwards of the same Biafran disease at the crisis refuge centre in Ibuza" (vi).

Loss serves as the central metaphor for Debbie's recollection and the central code to decipher her existence. Destination Biafra's narrative of the Biafran secessionist enclave develops into a semiotic of loss for scores of people of Igbo extraction who have been brutalized and traumatized, especially women and children who have anticipated that Republic of Biafra will provide the succor needed to actualize their humanity and dignity, but only for Biafra to become short lived. The novel's "Biafra narrative" is rooted in Debbie's painful experiences on her way to, and in Biafra. Indeed, pain and suffering are central to Debbie's recollection. Consequently, the Biafra narrative discloses itself as the despicable experience of futility and inexplicable suffering orchestrated by a deep-seated animosity between Saka Mohmoh and Chijioke Abosi. Whose consequences were borne by hapless women and children like Debbie, Uzoma Madako and the two Nwoba boys. Debbie's resolve not to agonise over Biafra's problems is underlined at the end of the novel:

There are two boys, the Nwoba boys, and many other orphans that I am going to help bring up with my share of Father's money. And there is my manuscript to publish. I shall tell those orphans the story of how a few ambitious soldiers from Sandhurst tried to make their dream a reality. (258)

For Debbie, memory embodies loss or pain so that Biafra narrative essentially requires concealing instead of unfolding. Remembering inevitably entails pain and, eventually, desires for repression transform into a necessity of repression. Debbie's experience of Biafra is transfigured into a discourse of repression and her recollection of Biafran experiences is translated into a narrative of loss. 
Memory as a motif of history is further reiterated by Derrida, "The memory we are considering here is not essentially oriented towards the past, toward a past present deemed to have really and previously existed. Memory stays with traces in order to "preserve" them, but traces of a past that has never been present, traces which themselves never occupy the form of presence and always remain, as it were, to come - come from the future, from the to come." (58)

Within the contemporary Nigerian context, Debbie's recollection of Biafran experiences demonstrates more of a loss of memory rather than a recalling of the past. Forgetting, paradoxically, becomes the key to memory. Recollection radically alters itself in a creative process. "Loss narrative" becomes the unconscious motif for the present remembrance, irretrievably lost beyond recall, made present only through a narrative that invites forgetting instead of remembering. Debbie's reflection of Biafra signifies nothing more than the loss of memories of vanished reality. The wanton killings, malnutrition of the children and the final destruction of Biafra, further strengthen Debbie's resolute decision to forget the memory of Biafra, "I see now that Abosi and his likes are still colonised. They need to be decolonised. I am not like him, and a woman of Africa. I am a daughter of Nigeria and if she is in shame, I shall stay and mourn with her in shame.' (258)

To Debbie, a member of the Itsekiri minority ethnic group, the doomed Biafra is ironically the locus that defines her sense of reality. Being a Nigerian and a member of a minority group only characterises her marginal existence. Recollection for Debbie, Uzoma Madako along with her two surviving children and the two Nwoba boys, reveals a process of negotiation with the past, constantly translating and revising the past into a narrative that grants reality to present situations. In a displaced context, these characters have constructed a Biafra narrative for themselves and for one another. It is indeed ironic that towards the end of the novel the Biafran soldiers who have been compelled to go to the MidWest to sue for solidarity at all cost at the risk of their lives, are compelled to tell the truth that they no longer remember, and tell them only after they have lost memory, "We are Biafrans, Ibos like you. His Excellency Abosi sent us to you. Look at our uniforms. One woman 
stepped boldly forward and said, Biafra. What is Biafra? You killed our man from this part, Nwokolo; the Nigerian soldiers came and killed what your soldiers left. We are Ibuza people, but we now live in the bush, thanks to your Abosi and your Biafra.' (230)

Biafra, so to speak, is a mirage, a repository of history with haunting memories and extraordinary experiences. Nigeria and Biafra narratives in Destination Biafra, with its attendant lopsidedness in a power equation created by the colonialists, snowballed into a political quagmire that produced inordinate ambitions in the greedy and overambitious political leader that were thrown up in the journey to independence. It further degenerated into a theatre of war that imbued the egos of the Nigerian and Biafran leaders. A strong will to keep Nigeria one even though forgotten to a certain extent, is what constitutes the locale of protest in the novel. Thus, the loss narrative is transformed into an authoritative discourse.

\section{History as motif of narration}

The novel's complex rendering of remembrance and repudiation, of memory and amnesia underscores Nigeria's complex stringing together of ethnic groups with incompatible differences, by the colonial authority. Manifestations of such differences are crucially important to an understanding of the nature of narrative that goes on within Destination Biafra. The novel does not protest simply by inveighing against the atrocities pitiless leaders inflict on a helpless populace; it however contends that a nation that is so insensitive as to forget what it did to itself in the name of political unity is indeed in trouble. In the narrative of Destination Biafra is inscribed semiotics of the physical scars of war and violence which may heal, but those inflicted on the psyche of Debbie, Uzoma, her children, and the two Nwoba boys may never be cured if Nigerians choose not just to deliberately forget or downplay the moral failings that led to mass killings on a national scale. To put it another way, a country that fails to remember what it should remember, and forget what it should forget is in danger of reliving its nightmares all over again.

This is a complicated form of protest: it apparently lacks the directness of the more common forms of protest that are a staple of 
national life, but it is symbolic of the indirect agitations staged by Nigerian expatriates like Emecheta, who were helpless to do anything else, given their location in a country six thousand miles away from the conflict. By emphasising the ambivalent nature of remembering and forgetting, she demonstrates that the commitment needed to protest is not contingent upon how close or how distant one is to conflict and trauma, but how genuine one's attitude is. Debbie is the scion of a well-connected and successful politician, one of those whose dilatoriness and ambition contributed significantly to the worsening of the impending tragedy, in fact. But she does not let this admittedly inescapable fact colour her moral response to the war; indeed, she regards herself as being in a particularly advantageous position to repair the damage done by her parents and their associates.

In Destination Biafra, Debbie Ogedemgbe serves as Emecheta's mouthpiece. Unlike her creator who by force of circumstances is away from her homeland, Debbie is fully involved in the issues, indeed more involved than most people. Through Debbie, the author is able to carefully trace the political history of Nigeria over the decades. In Debbie the boundaries between self and other are not clearly defined; in her, Nigeria narrative is confronted and re-inscribed. She is forced to negotiate her position between conflicting sets of discourses: of gender, family, ethnicity, culture, history and nationality. In order to reach reconciliation, Emecheta similarly has to come to terms with herself in relation to the historical situation she is protesting in Destination Biafra. Debbie refuses to live a hyphenated experience orchestrated by her repeated rape in her determination to get to Biafra to stop Abosi from continuing with the Biafran project. She manages to get to Biafra by subverting the burden placed on her by her gender. Debbie's courage in embarking on a mission to Biafra underscores Jean Block's argument that, "Sexual identity means... the earning of a sense of self that includes a recognition of gender secure enough to permit the individual to manifest human qualities that our society... has labeled (manly).'(2)

On one hand, Debbie resists the societal codification of her gender hegemonic narrative, and on the other hand, she rejects the maledominated notion that the army is an exclusive preservation of men by 
enlisting in the army. In Debbie is situated Emecheta's protest against the distorted history of Nigeria's past.

Emecheta's use of historical motif in the narrative of the Nigerian civil war is aimed at providing historical material for analysing the deprivation, hunger, rape, torture and general social miasma suffered by both men and women during the war. The feminisation of Debbie Ogedemgbe, who is neither Igbo nor Hausa, but from the minority Itsekiri, is to further underscore her condemnation of the political failings which led to the civil war and to demonstrate her fury at it.

Ogedemgbe's involvement in the civil war started when she enlisted in the Nigerian army at the beginning of the war. Debbie is somewhat close to Abosi, the leader of the breakaway Biafra. Momoh, the Nigerian head of state is convinced that Debbie could use her friendship with Abosi to persuade him to drop his determination to create the Republic of Biafra. Debbie has her first experience of the pain and anguish of war when she and her mother were raped by the soldiers in spite of her protestation that she is also an officer of the Nigerian army. At this juncture in the novel, protest is foregrounded in the transformation of Debbie from a complacent Oxford-educated daughter of a former minister of finance and one of the major casualties of the first military coup of January 1966.

The enlistment of Debbie in the Nigeria Army and the placement of the burden of negotiation on Debbie, for peaceful resolution in the tension between Abosi and Momoh is informed by Emecheta's feminist consciousness which seeks to deconstruct the stereotype that soldiering is mainly for men. Accordingly, Emecheta uses Debbie as a bridge between men and women, between Abosi and Momoh; she is a kind of agent of change, a mediator who helps Nigeria traverse the strange and uncertain frontiers of political crisis with its attendant challenges, prospect and opportunities.

\section{Deconstructing stereotypical image of women}

In Debbie's heroic movement from Nigeria to Biafra with its dangers and physical abuses, Emecheta neutralises the stereotype of women being seen as "mothers" and "mistresses," as well as the 
seemingly irreconcilable fissure between women as the "weaker sex" and the struggle for survival. In so doing, Emecheta unequivocally in Destination Biafra inscribes the importance of women in nation-building and national development. Women's resilience is imbued by the capability to adapt to new situations and circumstances more easily and quickly than men. Emecheta has been able to prove prima facie, in the image of Debbie, a sacrosanct historical truth about the war, that women can demonstrate the courage needed to survive difficult conditions. Grace Okereke has aptly commented on women as a symbol of courage in Destination Biafra, "By creating a self assertive, politically-informed heroine like Debbie Ogedemgbe, Emecheta has successfully taken woman from the periphery of Nigerian politics and made her an article of history .... Nigerian woman and indeed, the African woman, emerges from the shadows of history to become herself a subject of history on whom depends the redemption of many lives and the restoration of peace to a nation.'” (149)

Emecheta thus uses history to protest the ill-treatment of women by men and the need for society to embrace the significant role of women as harbingers of peace and justice. In the text, violence is centred mainly on women, depicting in vivid terms the rape and the torture they experience. The war narrative in the novel provides insights in two main ways: as a pretext to look at the past, at the political crisis created by the politicians who are predominantly male, and to revisit history. In the novel, Debbie's narrative and her perception of the degradation of women during the civil war serve as a point of departure to step back and reflect on history, on the rapport between memory and history, and how history is shaped by a writer. This notion is further reiterated in the view of Barbara W. Tuchman, "Good fiction, even if it has nothing to do with fact, is usually founded on reality and perceives truth - often more truly than some historians. It is exactly this quality of perceiving truth, extracting it from irrelevant surroundings and conveying it to the reader or the viewer of a picture, which distinguishes the artist. What the artist has is an extra vision and an inner vision plus the ability to express it. He supplies a view or an understanding that the viewer or reader would not have gained without the aid of the artist's creative vision." (46-47) 
The characters in Destination Biafra are fictionalised. They are historical representations of members of the Nigerian political class from the colonial administration to the first republic and during the civil war. For instance, Mallam Nguru Kano is Alhaji Tafawa Balewa. Sardauna in real life is Sir Ahmadu Bello; Chief Olusegun Odumosu in real life is Chief Obafemi Awolowo; Chief Durosaro, is Chief S. L. Akintola; Dr. Ozimba in real life is Dr. Nnamdi Azikiwe; Dr. Eze in real life is Dr. Kingsley Mbadiwe; Brigadier Ene Onyemere is General J. T. U. AguiyiIronsi; Samuel Ogedemgbe is Chief Omimi Ejoor Okotie-Eboh; Colonel Oladapo is Colonel Adekunle Fajuyi; Captain John Nwokolo is Major Nzeogwu Kaduna ; Colonel Saka Mohmoh is General Yakubu Gowon; Colonel Chijioke Abosi is Colonel Chukwuemeka Odumegwu Ojukwu .These are historical figures who played outstanding roles in the history of post-independent Nigeria. Chinyere Nwahunanya has explained the fictionalization of these characters as a negotiation between historicism and 'imaginative creation'(428).

Historically, these characters existed. Though fictionalized, the events, situations and characters in the novel are grounded firmly in historical reference, but they do far more than simply convey an ahistorical truth about Nigerian civil war. Emecheta historicizes violence, depravity and suffering in the novel to expose the manifestation of political imbalance in Nigeria. This underscores the notion, that anger, violence and threat of instability as prevalent in contemporary Nigeria, are not inherent, innate Nigerian characteristics; they are the direct result of years of colonial manipulation, ethinic chauvinism and military adventurism in Nigerian political history. It is significant to note that Emecheta is not primarily particular about dates, but relied strongly on Nigeria's historical past to analyse the country's political trajectory. Emecheta's technique resonates Akachi Ezeigbo's argument, that "The duty of the historian is to record and interpret as objectively as humanly possible the events of the past. But the historical novelist cannot be so restricted for he is at liberty to interpret history to suit his purpose; he could dramatise and reconstruct moments in history which he considers important to the reshaping of his people's destiny. Above all, his 
interpretation of history is creative and does not have to comply strictly with historical reality." (11)

Emecheta's employment of historical materials in Destination Biafra allows her to manipulate events, situations and characters as to represent the complexities of the past. Such representation is fundamental, because it is a story based on the imagination of the writer. By employing Nigeria's historical past, Emecheta has unavoidably imposed herself on the past by inventing narratives that strive to explain what the "past really meant," what the source-text "really says," what the author's intentions "really were." (600). This is in conformity with what Edmund Burke describes as, "literary images and metaphors that produce a reaction of terror and sublimity" Burke further interpreted such sublimity as that which 'excite(s) the ideas of pain,and danger, that is to say whatever is in any sort terrible, or is conversant about terrible objects, or operates in a manner analogous to terror'(131).

Emecheta in Destination Biafra interrogated the role of British and American governments in the political affair of Nigeria. The mentioning of names like Governor Macdonald and Captain Alan Grey, with their attendant meddlesomeness in the shaping of Nigeria's political landscape is strongly criticised in the novel. The manipulation of the first republic's election in favour of the Hausa-Fulani elements by British colonial authorities is protested in the novel. The effects of this manipulation eventually threw up political problems which degenerated into the civil war. Also, the role of Grey, as a double agent who serves as an adviser to Momoh, a friend to Biafra's Nwokolo, and whose advice was rebuffed by Abosi, is strongly condemned by Emecheta. Grey, even in the thick of the war gets to Biafra and is able to collate information on the strength of Biafra. He is also portrayed in the novel as a male chauvinist and racist. This is vividly captured at the end of the novel, when he asks Debbie to move with him to England, so that they could get married. Debbie, however, tactically refuses.

The Nigerian civil war is a sad reminder of the historical reality in Nigeria and its use in Emecheta's Destination Biafra provides an alternative narrative, which hitherto had been dominated by the maleauthored works, including Elechi Amadi's Sunset in Biafra; Cyprian 
Ekwensi's Divided We Stand; Chukwuemeka Ike's Sunset at Dawn and others. Emecheta anchors her civil war narrative on the platform of feminism. Even though the novel focuses on the psychological trauma of gender-specific suffering, the narrative achieves its success through the artistic presentation facilitated by the nexus between history and literature. As Hugh Webb succinctly asserts in his essay, 'The African Historical Novel and the Way Forward', "In the modern African historical novel the attempted dynamic rendering of these alternatives (by giving a total picture of a society in motion) Is an important motivating formal principle. It is clear that African novelists Proceed from this principle to create literary works that in their shaping and ordering, give significant insights into the potentialities of a fictional treatment of historical material''(24). Emecheta's historicization of the suffering of women during the war in conformity with Webb's assertion, marks a watershed in the corpus of Nigerian war literature.

In as much as literature is not history, it can be history, as literature is endowed with the facilities to examine the past. History does not have the equivalence of the imaginative literature in the sense that, "While the historian is preoccupied with actions and delineates the characters of men as much as he can deduce them from their actions, the historian is tellingly interested in the character as the novelist, but he can only comprehend of its existence when the character appears in the narrative.' (Forster 55)

The novelist gets more involved than the historian by employing imagination to articulate the inner feelings and thoughts of the character. George Lukacs upholds this notion, when he posits that, "What matters therefore, in the historical novel is not the re-telling of great historical events, but the poetic awakening of the people who figured in these events. What matters is that we should re-experience the social and human motives which led men to think, feel and act just as they did in historical reality'(42). By appropriating appurtenances of history: allegorization of imbalance in distribution of political positions between Northern and Southern Nigeria; political crisis shortly after independence in Western Nigeria; Nigerian civil war of 1967-1970 and ethnic chauvinism among Nigerian civilian/military ruling class, constitute semiotics of interplay of history and literature which Emecheta 
significantly harnessed to render a scintillating narrative of Nigeria project in Destination Biafra.

\section{Conclusion}

It is suffice to note that earlier literary works on the Nigerian civil war were written by Igbo writers, who largely presented the war from the biased and sentimental point of view of the Biafran forces and their supporters, as demonstrated in Mezu's Behind the Rising Sun, Ike's Sunset at Dawn, and Munonye's A Wreath for the Maidens . Nevertheless, a number of works written by non-Igbo writers, like Iyayi's Heroes and Okpewho's The Last Duty, with considerable level of objectivity, have also presented the psychological and human trauma experienced by the people from both divides of Nigeria and Biafra. Emecheta's Destination Biafra, as a novel written by an Igbo writer, has succeeded in presenting a somewhat fusion of events from Nigeria's political history, significantly moderated by literary imagination, such presentation unobtrusively created a fair assessment of the Nigerian civil war from the two divides. The adoption of Debbie Ogedemgbe a minority, as a mouthpiece in the novel, affords Emecheta a convenient platform of neutrality and non-partisanship. One cannot but acknowledges Emecheta's pioneering effort at evaluating and assessing from feminist point of view; the devaluation, brutality and transcendental psychological trauma suffered by women during the Nigerian civil war, which were glossed over in male-authored war novels.

Emecheta in Destination Biafra, through the mediation of feminism and historicism has sufficiently articulated the most traumatic event of Nigeria's post-independence history in order to retell it from a new perspective that would throw fresh insight on the self-destructive propensities of its people. From the authorial perspective, war is presented as an unmitigated and senseless tragedy, amplified by a relentless succession of gratuitous killings and maiming. 


\section{References}

Achebe, Chinua. A Man of the People. New York: The John Day Company, 1966.

Acholonu. Catherine .'Buchi Emecheta.' The Guardian Literary Series, The Guardian, Saturday, January 25,1986 p.13.

Adams,Marie, Ann.' 'It's a woman's war: Engedering conflict in Buchi

Emecheta's Destination Biafra'. Callaloo 24:1 (2001), 287-300.

Adichie, Chimamanda, Ngozi. Half of the yellow Sun. New York: Knopf,2006.

Allende, Isabel. "Writing as an act of Hope' PP.41-63 in Paths of

Resistance: The Art and Craft Of the Political Novel, ed. William Zinsser. Boston: Houghton Mifflin,Co.,1989.

Block, Jeane H. Sex Role Identity and Ego Development. London: Jossey-Bass Publishers, 1984

Burke, Edmund. A philosophical Enquiry into the origin of Our Ideas of the Sublime and Beautiful. Ed. J.T . Boulton. London ;Routledge,1958.

Derrida, Jacques. Memoires:For Paul de Man.Trans. Cecile Lindsay et al. New York:Columbia UP,1989:58

Emecheta, Buchi. Destination Biafra. London: Allison and Busby Ltd. 1982.

Ezeigbo, Akachi Theodora. "History and the Novel in Africa" in Ernest

N. Emenyonu (ed.) African Literature and African Historical

Experience, Ibadan: Heinemann, 1991:11.

Forster,E.M. Aspects of the Novel. Harmondsworth, Middlesex:Penguin, 1976.

Griffiths, Gareth. African Literature in: English East and West. London: Pearson Education, 2000.

Gordimer, Nadine. The Black Interpreters. Johannesburg: SPROCAS/Ravan, 1973.

Hawley, John C. ' Biafra as Heritage and symbol:Adichie,Mbachu and Iweala.' 'Research in African Literature 39:2(2008).15-26.

Iroh, Eddie. The Siren in the Night. London: Heinemann, 1982. Jones, Eldred Durosimi. 'New Trends and Generations in African 
Literature.' African Literature Today, 20 (1996),1-2.

Lukacs, Georg. The Historical Novel, New Jersey: Modern Humanities Press, 1962.

Maier,Karl. This House Has Fallen. England: Penguin Books, 2001. Nwahunanya, Chinyere. 'The Aesthetics of Nigerian War Fiction'.

Fiction Studies 37.3(1991).

Nwahunanya,Chinyere. 'Introduction' Ed. Chinyere Nwahunanya, A

Harvest from Tragedy : Critical Perspectives on Nigerian Civil

War Literature, Owerri: Springfield,1997:14.

McLuckie, Craig W. Nigerian Civil War Literature:Seeking an Imagined Community.' Lewiston, Ny: Edwin Mellen Press, 1990.

Okereke, Grace. "The Nigerian Civil War and the Female Imagination" in Helen Chukwumema (ed.), Feminism in African Literature, Enugu, Lagos, Abuja: New Generation Books, 1994: 149.

Tuchman, W. Barbara. Practising History, New York: Ballantine Books, 1981.

Uko, Iniobong I. 'Transcending the Margins: New Directions in Women's Writing' African Literature Today, 25(2006),82.

Webb, Hugh. 'The African Historical Novel and the Way Forward', African Literature Today, 11(1980),24-38. 